
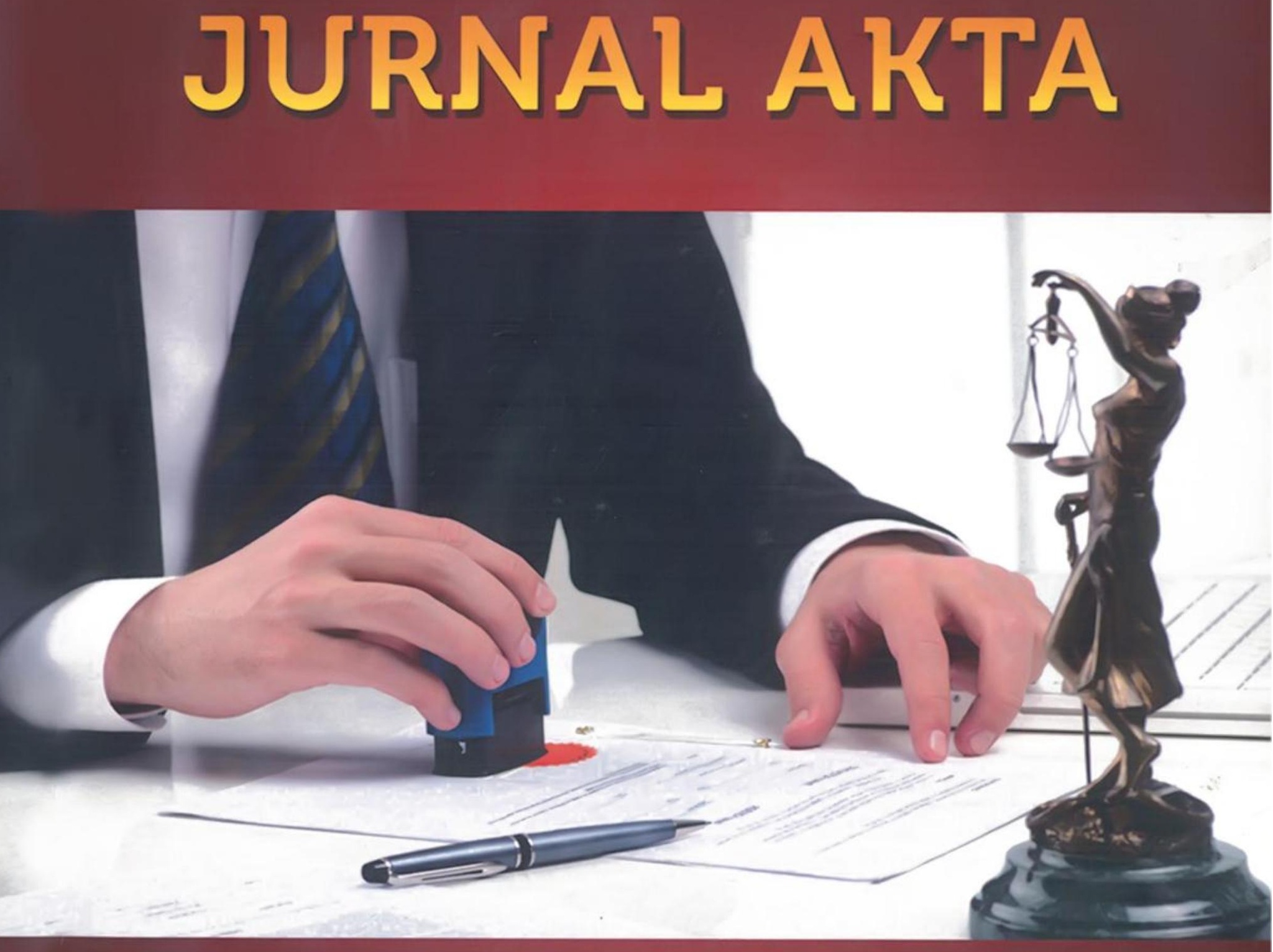

Program Magister (S2) Kenotariatan

Fakultas Hukum Unissula Semarang

\begin{tabular}{|l|c|c|c|c|c|}
\hline JURNAL AKTA & Vol.VII & No.1 & $\begin{array}{c}\text { Halaman } \\
1-204\end{array}$ & $\begin{array}{c}\text { FH } \\
\text { UNISSULA }\end{array}$ & $\begin{array}{c}\text { ISSN } \\
2406-9426\end{array}$ \\
\hline
\end{tabular}




\section{DAFTAR ISI}

\begin{tabular}{|c|c|}
\hline Pengantar Redaksi & I \\
\hline Daftar Isi & ii \\
\hline $\begin{array}{l}\text { Keabsahan Pembuatan Akta Notaris Dengan Menggunakan Media } \\
\text { Elektronik Dalam Kaitannya Dengan Implementasi Undang- } \\
\text { Undang Nomor } 11 \text { Tahun } 2008 \text { Tentang Informasi Dan Transaksi } \\
\text { Elektronik } \\
\text { Oleh : Ari Widiyanto, Sukarmi }\end{array}$ & $1-9$ \\
\hline $\begin{array}{l}\text { Pelaksanaan Penyelesaian Kredit Macet Yang Diikat Dengan Hak } \\
\text { Tanggungan Di PT Bank Tabungan Pensiunan Nasional Mitra } \\
\text { Usaha Rakyat Cabang Tegal } \\
\text { Oleh : Gilang Bayuaji, Sukarmi }\end{array}$ & $10-19$ \\
\hline $\begin{array}{l}\text { Peran Notaris Dalam Memberikan Pemahaman Hukum Kepada } \\
\text { Masyarakat Yang Kurang Mampu Dalam Memahami Hukum } \\
\text { Kaitannya Dalam Pembuatan Akta-Akta Notariil Di Wilayah Kedu } \\
\text { Selatan } \\
\text { Oleh : Rahmat Solehan, Gunarto }\end{array}$ & $20-29$ \\
\hline $\begin{array}{l}\text { Keberadaan Akta Notaris Terkait Proses Pemberesan Harta Pailit } \\
\text { Berdasarkan Undang-Undang Nomor } 37 \text { Tahun } 2004 \text { Tentang } \\
\text { Kepailitan Dan Penundaan Kewajiban Pembayaran Utang } \\
\text { Oleh : Intan Ayu Widyowati, Gunarto }\end{array}$ & $30-38$ \\
\hline $\begin{array}{l}\text { Peran Ppat Dalam Peerkara Penguasaan Seepihak Atas Tanah Harta } \\
\text { Warisan (Putusan P.A. Sbr No : 2594/Pdt.G/ 2015) } \\
\text { Oleh : Sodik, Anis Mashdurohatun }\end{array}$ & $39-50$ \\
\hline $\begin{array}{l}\text { Perlindungan Hukum Bagi Pihak Ketiga Atas Hak Konstitusional } \\
\text { Warga Negara Dalam Hak Penguasaan Tanah Dan Bangunan Hasil } \\
\text { Perkawinan Beda Kewarganegaraan Pasca Putusan Mahkamah } \\
\text { Konstitusi No. } 69 \text { /Puu-Xiii/2015 (Studi Analisis Hak Kepemilikan } \\
\text { Rumah Dan Bangunan Di Jakarta) } \\
\text { Oleh : Achmad Jumeri Pamungkas, Akhmad Khisni }\end{array}$ & $51-64$ \\
\hline $\begin{array}{l}\text { Tinjauan Hukum Dan Akibatnya Terhadap Wasiat Tanpa Akta } \\
\text { Notaris Ditinjau Dari Kompilasi Hukum Islam Dan Kitab Undang- } \\
\text { Undang Hukum Perdata } \\
\text { Oleh : Adam Lukmanto, Munsyarif Abdul Chalim }\end{array}$ & $65-74$ \\
\hline $\begin{array}{l}\text { Problematika Perwakafan Dan Penyelesaian Sengketa Hukumnya } \\
\text { (Studi Kasus Di Pengadilan Agama Semarang) } \\
\text { Oleh : Agung Wicaksono, Munsyarif Abdul Chalim }\end{array}$ & $75-84$ \\
\hline $\begin{array}{l}\text { Studi Perbandingan Peran Notaris Dalam Perspektif Hukum Islam } \\
\text { Dan Hukum Positif Kaitannya Dengan Pelayanan Terhadap } \\
\text { Masyarakat } \\
\text { Oleh : Ahmad Ridwan, M. Hafidh }\end{array}$ & $85-99$ \\
\hline
\end{tabular}




\begin{tabular}{|c|c|}
\hline $\begin{array}{l}\text { Mekanisme Roya Hak Atas Tanah Yang Merupakan Agunan } \\
\text { Debitor Pada Perbankan Yang Dilelang Oleh Pejabat Lelang } \\
\text { Karena Kreditnya Macet (Studi Kasus Risalah Lelang Nomor } \\
786 / 2015 \text { Sertipikat Hak Milik Nomor } 240 \text { Desa Pasusukan } \\
\text { Kecamatan Bawang Kabupaten Batang) } \\
\text { Oleh : Fredy Bagus Kusumaning Yandi, Umar Ma'ruf }\end{array}$ & $100-110$ \\
\hline $\begin{array}{l}\text { Perlindungan Hukum Terhadap Jabatan Notaris Yang Diduga } \\
\text { Melakukan Malpraktek Dalam Proses Pembuatan Akta Otentik } \\
\text { Oleh : Entin Sholikhah, Jawade Hafidz }\end{array}$ & $111-119$ \\
\hline $\begin{array}{l}\text { Peran Notaris Dalam Implementasi Asas Nemo Plus Yuris Dan } \\
\text { Itikad Baik Dalam Peralihan Hak Atas Tanah Sebagai Dasar } \\
\text { Pembuktian Bagi Pemiliknya } \\
\text { Oleh : Sawin Dwi Hapsari, Jawade Hafidz }\end{array}$ & $120=130$ \\
\hline $\begin{array}{l}\text { Peran Pejabat Pembuat Akta Tanah Terhadap Pemasangan Hak } \\
\text { Tanggungan Dengan Nama Sertifikat Hak Milik Yang Telah Meninggal } \\
\text { Dunia Yang Dilakukan Proses Turun Waris Kepada Ahli Waris Berbasis } \\
\text { Keadilan } \\
\text { Oleh : Dian Melina, Lathifah Hanim }\end{array}$ & $131-143$ \\
\hline $\begin{array}{l}\text { Peranan Notaris Dalam Memberikan Perlindungan Hukum } \\
\text { Terhadap Konsumen Kredit Pemilikan Rumah Melalui Perjanjian } \\
\text { Baku Berdasarkan Undang-Undang Nomor } 8 \text { Tahun } 1999 \text { Tentang } \\
\text { Perlindungan Konsumen } \\
\text { Oleh : Mohammad Tohir, Gunarto }\end{array}$ & $144-156$ \\
\hline $\begin{array}{l}\text { Penerapan Asas Proporsionalitas Dalam Pembuatan Akta Perjanjian } \\
\text { Kerjasama Oleh Notaris (Akta Perjanjian Kerjasama Pemilik } \\
\text { Sarana Apotek (Psa) Dengan Apoteker Pengelola Apotek (Apa)) } \\
\text { Oleh : Ahmad Syaikhu, D. Djunaedi }\end{array}$ & $157-168$ \\
\hline $\begin{array}{l}\text { Aspek Hukum Risalah Lelang Sebagai Akta Otentik Dalam Lelang } \\
\text { Eksekusi Hak Tanggungan } \\
\text { Oleh : Rujiati, Amin Purnawan }\end{array}$ & $169-180$ \\
\hline $\begin{array}{l}\text { Implikasi Peraturan Pemerintah Nomor } 24 \text { Tahun } 2016 \text { Perubahan } \\
\text { Dari Peraturan Pemerintah Nomor } 37 \text { Tahun } 1998 \text { Tentang Jabatan } \\
\text { Ppat Terhadap Daerah/Wilayah Kerja Ppat } \\
\text { Oleh : Indah Suryaningsih, Umar Ma'ruf }\end{array}$ & $181-192$ \\
\hline $\begin{array}{l}\text { Kajian Normatif Penertiban Tanah Terlantar Status Hak Guna } \\
\text { Usaha Berdasarkan Peraturan Pemerintah Nomor } 11 \text { Tahun 2010 Di } \\
\text { Kabupaten Sambas } \\
\text { Oleh: Asbi Aliakbar, Anis Mashdurohatun }\end{array}$ & $193-204$ \\
\hline
\end{tabular}




\title{
PELAKSANAAN PENYELESAIAN KREDIT MACET YANG DIIKAT DENGAN HAK TANGGUNGAN DI PT BANK TABUNGAN PENSIUNAN NASIONAL MITRA USAHA RAKYAT CABANG TEGAL
}

\author{
Oleh: Gilang Bayuaji \\ Sukarmi \\ email : gilang_bayuaji@yahoo.co.id
}

\begin{abstract}
ABSRAK
Salah satu ciri Hak Tanggungan yang kuat adalah mudah dan pasti dalam pelaksanaan eksekusinya, jika debitur cidera janji. Hal tersebut diwujudkan dengan disediakannya cara-cara pelaksanaan eksekusi yang lebih mudah daripada melalui gugatan seperti perkara perdata biasa. Namun dalam prakteknya banyak terdapat hambatan-hambatan dalam pelaksanaan dari hak eksekutorial yang terdapat pada Hak Tanggungan. Dengan adanya bantahan tersebut maka pihak kreditur yang piutangnya telah dijamin dengan Hak Tanggungan, tertunda dalam melaksanakan hak sesuai peraturan tentang Hak Tanggungan yaitu hak eksekutorial. Dalam penelitian ini akan dibahas tentang kekuatan eksekutorial dari sertipikat Hak Tanggungan dalam pemenuhan hak-hak para pihak yang terikat dalam jaminan dengan Hak Tanggungan serta prosedur dan kekuatan eksekutorial dari sertipikat Hak Tanggungan dalam pemenuhan hak-hak para pihak sudah terpenuhi dalam proses Eksekusi Hak Tanggungan.

Penelitian ini bersifat deskriptif analitis dengan pendekatan yuridis normatif, data diperoleh, melalui penelitian kepustakaan dan penelitian lapangan sebagai penguat. Selanjutnya data dianalisis secara kualitatif.

Dari hasil penelitian ini disimpulkan, Undang-Undang Hak Tanggungan telah memberikan kekuatan eksekutorial yang besar kepada sertifikat Hak Tanggungan, yaitu dengan dicantumkannya irah-irah yang berbunyi "Demi Keadilan Berdasarkan Ketuhanan Yang Maha Esa”, sehingga kedudukan dari sertifikat Hak Tanggungan sama dengan Putusan Pengadilan yang telah memperoleh kekuatan hukum tetap.
\end{abstract}


Adapun cara untuk melaksanakan kekuatan eksekutorial yang dimiliki oleh sertifikat Hak Tanggungan dilakukan melalui dua cara yaitu eksekusi langsung yang didasarkan pada ketentuan Pasal 6 Undang-Undang Hak Tanggungan dan eksekusi melalui titel eksekutorial yang diatur dalam pasal 20 ayat (1) UndangUndang Hak Tanggungan dan kekuatan eksekutorial yang dimiliki oleh Hak Tanggungan telah dijalankan sesuai dengan aturan eksekusi Hak Tanggungan yang diatur dalam Undang- Undang Hak Tanggungan. Sehingga pemenuhan hakhak para pihak juga terlaksana dengan baik.

Kata kunci: perjanjian, kredit dan eksekusi jaminan

\section{A. PENDAHULUAN}

\section{Latar Belakang}

Pembangunan ekonomi, sebagai bagian dari pembangunan nasional merupakan salah satu upaya untuk mewujudkan kesejahteraan rakyat yang adil dan makmur berdasarkan Pancasila dan Undang-Undang Dasar 1945. Dalam rangka memelihara kesinambungan pembangunan tersebut yang para pelakunya meliputi baik pemerintah maupun masyarakat sebagai orang-perorangan dan badan hukum, sangat diperlukan dana dalam jumlah yang besar. Bertambah meningkatnya pembangunan nasional yang bertitik berat pada bidang ekonomi, dibutuhkan penyediaan dana yang cukup besar, sehingga memerlukan lembaga hak jaminan yang kuat dan mampu memberi kepastian hukum bagi pihak-pihak yang berkepentingan, yang dapat mendorong peningkatan partisipasi masyarakat dalam pembangunan untuk mewujudkan masyarakat yang sejahtera, adil, dan makmur.

Bank adalahsebuah badan yang aktivitasnya meliputi kegiatan penerimaan dana dari masyarakat dalam berbagai bentuknya (giro, deposito, tabungan dan lainnya) yang sudah jelas memerluka persyaratan khusus untuk mendirikannya. ${ }^{1}$

\footnotetext{
${ }^{1}$ Zaenal asikin, 1997,pokok-pokok hukum perbankan, jakarta, hal 25
} 
Apabila Bank menerima permohonan kredit dari nasabah bank ataupun pihak lainnya, maka bank perlu melakukan analisis terlebih dahulu terhadap permohonan kredit tersebut, analisis yang dilakukan bank tersebut meliputi: ${ }^{2}$

1. Character (watak);

2. Capacity (kemampuan);

3. Capital (modal);

4. Collateral (jaminan);

5. Condition (keadaan).

Salah satu unsur yang penting dalam analisis tersebut adalah jaminan yang diberikan oleh debitur, jaminan berarti harta kekayan yang dapat diikat sebagai jaminan guna menjamin kepastian pelunasan hutang jika dikemudian hari debitur tidak dapat melunasi hutangnya yaitu dengan jalan menjual jaminan dan mengambil pelunasan dari penjualan harta kekayaan yang menjadi jaminan tersebut.

Wanprestasi yang dimaksut jika kreditur tidak melakukan apa yang dijanjikan, maka ia melakukan wanprestasi, ia ingkar janji, atau melanggar perjanjian, bila ia melakukan atau berbuat sesuatu yang tidak boleh dilakukannya. ${ }^{3}$

Perkataan wanprestasi sebagaimana yang dijelaskan di atas mempunyai hubungan dengan perkataan kredit macet, sebagaimana diketahui bahwa tidak semua kredit yang diberikan kepada debitur dapat dikembalikan dengan baik karena biasanya pengembaliannya sebagian akan lancar dan sebagian lagi akan menuju kearah kemacetan. ${ }^{4}$

Untuk menyelamatkan kredit macet tersebut Bank melakukan penjadwalan kembali dengan debitur terhadap pemenuhan kredit yang dituangkan dalam Persetujuan Perpanjangan. Dalam perkembangan selanjutnya Bank juga melakukan pengurangan utang debitur dari Rp.

2 Abdulkadir Muhamad, Segi Hukum Lembaga keuangan dan Pembiayaan, (Bandung: Citra Aditya Bakti, 2000), hlm. 82.

${ }^{3}$ Subekti, Hukum Perjanjian, (Jakarta: PT Intermasa, 1998), hlm. 45.

${ }^{4}$ Muchdarsyah Sinungan, Manajemen Dana Bank (Bumi Aksara, 2000), hlm. 168. 
500.000.000,-(lima ratus juta rupiah) menjadi Rp. 400.000.000,-(empat ratus juta rupiah). Dengan itikad untuk melakukan penyelamatan kredit Bank melakukan penjadwalan kembali untuk yang kedua kalinya atas utang debitur. Ternyata walaupun telah dilakukan penjadwalan kembali untuk yang kedua kalinya debitur masih tidak melakukan pemenuhan atas kewajibannya.

Maka kreditur akhirnya memutuskan untuk melakukan eksekusi terhadap jaminan yang diberikan oleh debitur yaitu Hak Tanggungan. Untuk melakukan eksekusi Hak Tanggungan yang dilaksnakan oleh “Kantor Pelayanan Kekayaan Negara dan Lelang” KPKNL.

Berdasarkan latar belakang yang telah dikemukakan di atas maka penulis sangat tertarik untuk melakukan penelitian lebih lanjut yang akan dituangkan dalam bentuk Tesis dengan judul : "Pelaksanaan Penyelesaian Kredit Macet Yang Diikat Dengan Hak Tanggungan Di PT. Bank Tabungan Pensiunan Nasional Mitra Usaha Rakyat Cabang Tegal'’.

\section{Rumusan Masalah}

Adapun rumusan masalahnya adalah sebagai berikut:

1. Bagaimanakah pelaksanaan penyelesaian kredit macet yang diikat dengan hak tanggungan di PT Bank Tabungan Pensiunan Nasional Mitra Usaha Rakyat Cabang Tegal?

2. Apa hambatan yang terjadi dan apa solusinya dalam pelaksanaan penyelesaian kredit macet yang diikat dengan hak tanggungan?

3. Bagaimanakah pelaksanaan eksekusi hak tanggungan apabila debitur wanprestasi dalam perjanjian kredit yang diikat dengan hak tanggungan?

\section{B. Pembahasan}

1. Pelaksanaan Penyelesaian Kredit Macet yang diikat dengan Hak Tanggungan di PT Bank Tabungan Pensiunan Nasional Mitra Usaha 


\section{Rakyat Cabang Tegal?}

Tindakan penyelesaian kredit bermasalah yang dilakukan oleh PT. BTPN Cabang Tegal disini adalah dengan melakukan tindakan restrukturisasi pinjaman, pengalihan fasilitas dan pelunasan sebagian atau seluruhnya. $^{5}$

\section{a. Rescheduling}

Adalah upaya penyelamatan kredit dengan melakukan perubahan syarat-syarat perjanjian kredit dengan melakukan perubahan yang di kenakan dengan jadwal pembayaran kembali kredit atau jangka waktu, termasuk grace period baik termasuk besarnya jumlah angsuran atau tidak.

\section{b. Reconditioning}

Adalah upaya penyelamatan kredit dengan cara melakukan perubahan atas seluruh syarat perjanjian kredit yang tidak terbatas hanya kepada perubahan jadwal angsuran atau jangka waktu kredit saja, namun perubahan tersebut tannpa memberikan tambahan kredit atau tanpa melakukan konversi atas seluruh atau sebagian dari kredit menjadi equity perusahaan.

\section{c. Restructuring}

Adalah upaya penyelamatan dengan melukan perubahan syarat perjanjian kredit atau melakukan konversi atas seluruh kredit menjadi equity perusahaan.

2. Hambatan Yang Terjadi Dan Apa Solusinya Dalam Pelaksanaan Penyelesaian Kredit Macet Yang Diikat Dengan Hak Tanggungan?

\footnotetext{
${ }^{5}$ Wawancara dengan Bpk. Andri, SE., Account Officer BTPN Cab. TEGAL, Tanggal 21 Februari 2017
} 
Berdasarkan hasil wawancara dan questioner penulis dengan informan (narasumber) dari penelitian lapangan yang telah penulis lakukan, maka faktor-faktor yang menjadi hambatan terjadinya Kredit Bermasalah Dalam Perjanjian Kredit Dengan Jaminan Hak Tanggungan adalah sebagai berikut:

Secara garis besar faktor-faktor yang dapat menjadi hambatan terjadinya kredit bermasalah dapat digolongkan menjadi faktor internal dan faktor eksternal, faktor intern Bank sebagai penyebab kredit bermasalah antara lain: ${ }^{6}$

1. Rendahnya Kemampuan Atau Ketajaman Bank Melakukan Analisis Kelayakan Permintaan Kredit Yang Diajukan Oleh Debitur.

2. Lemahnya Sistem Informasi Kredit Serta Sistem Pengawasan Dan Administrasi Kredit Mereka.

3. Campur Tangan Yang Berlebihan Dari Para Pemegang Saham Bank Dalam Keputusan Pemberian Kredit.

4. Pengikatan Jaminan Kredit Yang Kurang Sempurna.

Peraturan pemerintah yang dikeluarkan untuk mengembangkan kondisi ekonomi keuangan atau sektor-sektor usaha tertentu, kadangkadang membawa dampak kurang menguntungkan bagisector usaha yang lain. Apabila bidang usaha debitur kebetulan terkena dampak kurang menguntungkan dari peraturan pemerintah tertentu, maka peraturan tersebut dapat menjadi sebab menurunnya hasil usaha dan likuiditas keuangan mereka.

Dalam banyak kejadian, penurunan hasil penjualan produk bahkan dapat mengakibatkan debitor menderita kerugian. Oleh karena sumber dana intern perusahaan untuk membayar kembali kredit adalah laba sesudah pajak dan dana penyusutan, maka menurunnya keuntungan akan menurunkan kemampuan debitur melunasi kredit.

\footnotetext{
${ }^{6}$ Wawancara dengan Bpk. Danny, SE., Bagian SPV MUR BTPN Cab. Tegal, Tanggal 21 Februari
} 2017 
Ada 4 (empat) macam faktor ekstern penyebab kredit bermasalah, yaitu: ${ }^{7}$

a. Kegagalan usaha debitur;

b. Menurunnya kegiatan ekonomi dan tingginya suku bunga kredit;

c. Pemanfaatan iklim persaingan dunia perbankan yang tidak sehat oleh debitur yang tidak bertanggung jawab, dan;

d. Musibah yang menimpa perusahaan debitur.

\section{Pelaksanaan Eksekusi Hak Tanggungan Apabila Debitur Wanprestasi Dalam Perjanjian Kredit Yang Diikat Dengan Hak Tanggungan?}

Berdasarkan hasil penelitian yang penulis teliti pada responden, Apabila debitor wanprestasi dalam pelaksanaan perjanjian kredit pihak bank tidak langsung melakukan eksekusi, akantetapi tetap berusaha melakukan pendekatan persuasif terhadap nasabah. Pendekatan ini dilakukan agar sedapat mungkin diperoleh penyelesaian kredit bermasalah secara damai tanpa melalui eksekusi.

Apabila hal ini juga tidak direspon oleh debitor/pemberi Hak Tanggungan, lalu berdasarkan sertifikat Hak Tanggungan yang menjadi jaminan kredit debitur, bank mengajukan permohonan eksekusi Hak Tanggungan kepada Ketua Pengadilan setempat.

Cara eksekusi yang digunakan demikian adalah merupakan upaya terakhir yang dapat dilakukan, karena sebelumnya ada cara yang sifatnya tidak ada unsur paksaan oleh kreditur kepada debitur untuk memenuhi kewajibannya yaitu penjualan dibawah tangan atas kesepakatan kedua belah pihak dan penjualan melalui lelang.

\footnotetext{
${ }^{7}$ Wawancara dengan Ibu Evvi Linny, ABSS BTPN MUR Tegal, Tanggal 22 Februari 2017
} 
Pelaksanaan lelang eksekusi Hak Tanggungan berdasarkan Pasal 6 Undang-Undang Nomor 4 Tahun 1996, sesungguhnya tidak memerlukan fiat pengadilan akan tetapi ketentuan mengenai fiat/penetapan pengadilan masih sering dipersoalkan baik oleh bank selaku kreditur/pemegang Hak Tanggungan maupun Pengadilan Negeri.

Untuk itu alangkah baiknya Pengadilan Negeri dilibatkan pada awal kredit, dalam hal mengeluarkan Rekomendasi kepada debitor pada saat pihak bank/kreditur merealisasikan perjanjian kredit tersebut. Adapun bunyi dari rekomendasi itu adalah sebagai berikut:

a. Debitur ini layak untuk mendapatkan kredit/pembiayaan dari bank;

b. Debitur akan bertanggung jawab apabila wanprestasi, akan diserahkan kepada KP2LN untuk dijual secara lelang dengan menggunakan Pasal 6 Undang-Undang Nomor 4 Tahun 1996.

\section{Penutup}

\section{Kesimpulan}

a) Penyelesaian kredit bermasalah dalam perjanjian kredit pada lembaga perbankan dengan jaminan hak tanggungan, bahwa penyelesaian secara damai merupakan upaya penyelesaian kredit yang dilakukan berdasarkan kesepakatan antara bank dengan debitur yang masih mempunyai itikad baik maupun kooperatif dalam upaya penyelesaiankredit bermasalah.

Kemudian penyelesaian selanjutnya dengan penagihan yang dilakukan dengan mendatangi debitur secara langsung, dan debitur diminta melakukan pembayaran dalam jumlah tertentu dari kewajibannya kepada bank dalam jangka waktu tertentu yang dituangkan dalam Surat Pernyataan Kesanggupan Debitur.

b) Faktor-faktor yang menjadi penyebab terjadinya kredit bermasalah dalam perjanjian kredit adalah sebagai berikut:

Faktor intern bank, yang meliputi: 
1) Rendahnya kemampuan atau ketajaman bank melakukan analisis kelayakan permintaan kredit yang diajukan oleh debitur;

2) Lemahnya sistem informasi kredit serta sistem pengawasan dan administrasi kredit mereka;

3) Campur tangan yang berlebihan daripara pemegang saham bank dalam keputusan pemberian kredit; dan

4) Pengikatan jaminan kredit yang kurang sempurna.

Faktor ekstern, yang meliputi:

1) Kegagalan usaha debitur;

2) Menurunnya kegiatan ekonomi dan tingginya suku bunga kredit;

3) Pemanfaatan iklim persaingan dunia perbankan yang tidak sehat oleh debitur yang tidak bertanggung jawab, dan;

4) Musibah yang menimpa perusahaan debitur.

c) Pelaksanaan Eksekusi Hak Tanggungan apabila debitor wanprestasi dalam perjanjian kredit, bahwa pihak bank tidak langsung melakukan eksekusi, akan tetapi tetap berusaha melakukan pendekatan persuasive terhadap nasabah. Pendekatan ini dilakukan agar sedapat mungkin diperoleh penyelesaian kredit bermasalah secara damai tanpa melalui eksekusi. Untuk itu upaya-upaya penyelamatan kredit yang dapat dilakukan oleh bank adalah : Rescheduling, Reconditioning, dan Restructuring. Proses litigasi akan ditempuh oleh bank, apabila nasabah debitur beritikad tidak baik, maka berdasarkan sertifikat Hak Tanggungan yang menjadi jaminan kredit debitur dapat dilakukan eksekusi menurut Undangundang Nomor 4 Tahun 1996, tetapi dalam realita praktek harus ada persetujuan fiat eksekusi dulu dari Ketua Pengadilan Negeri. 


\section{DAFTAR PUSTAKA}

Zaenal asikin, 1997,pokok-pokok hukum perbankan, jakarta

Abdulkadir Muhamad, Segi Hukum Lembaga keuangan dan Pembiayaan, (Bandung: Citra Aditya Bakti, 2000)

Subekti, Hukum Perjanjian, (Jakarta: PT Intermasa, 1998)

Muchdarsyah Sinungan, Manajemen Dana Bank (Bumi Aksara, 2000)

Wawancara dengan Bpk. Andri, SE., Account Officer BTPN Cab. TEGAL, Tanggal 21 Februari 2017

Wawancara dengan Bpk. Danny, SE., Bagian SPV MUR BTPN Cab. Tegal, Tanggal 21 Februari 2017

Wawancara dengan Ibu Evvi Linny, ABSS BTPN MUR Tegal, Tanggal 22 Februari 2017 